\title{
3D Natural State Modeling of Mount Iyang-Argopuro Geothermal Area, East Java, Indonesia
}

\author{
Dewi Asmorowati ${ }^{1, *}$, Allen Haryanto Lukmana ${ }^{1}$, Rizqi Mahfudz Prasetyo ${ }^{1}$ \\ ${ }^{I}$ Department of Petroleum Engineering, Faculty of Mineral Technology, Universitas Pembangunan Nasional "Veteran” Yogyakarta, Sleman, Special Region of \\ Yogyakarta, Indonesia.
}

* Corresponding author : dewi.asmorowati@upnyk.ac.id

Tel.:+62-82136883399

Received: Nov 27, 2019; Accepted: Jun 8, 2021

DOI: 10.25299/jgeet.2021.6.2.4127

\section{Abstract}

Mount Iyang-Argopuro is one of the geothermal working areas in the East Java. Mount Iyang-Argopuro has the potential of 185 MWe of reserves and $110 \mathrm{MWe}$ of resources. It is estimated to have a liquid dominated reservoir with temperature up to $250-275^{\circ} \mathrm{C}$. An early $3 \mathrm{D}$ natural state numerical model of Mount Iyang-Argopuro Field is created using TOUGH2 simulator in order to identify the undisturbed condition of reservoir and resource assessment. Since Mount Iyang-Argopuro geothermal area is still in the exploration stage, the model created based on based on geological, geophysical, and geochemical data. The model has an area $14 \mathrm{~km} \mathrm{x} 8.2 \mathrm{~km}$ and $9180 \mathrm{~m}$ in thickness. The model consists of 7410 of rectangular cell blocks with the roughest cell size is $1000 \mathrm{~m}$ x $1000 \mathrm{~m}$ and the finest is $200 \mathrm{~m}$ x $500 \mathrm{~m}$. The model is verified by matching the model temperature and pressure profiles to the calculated geothermometer temperature and pressure, which shows good match enough.

Keywords: Mount Iyang-Argopuro; Natural State; Reservoir Simulation; TOUGH2

\section{Introduction}

Mount Iyang-Argopuro geothermal system of is one of Indonesia's geothermal prospect area which located in Bondowoso Region, Jember Region, Probolinggo Region, and Situbondo Region, East Java Province.

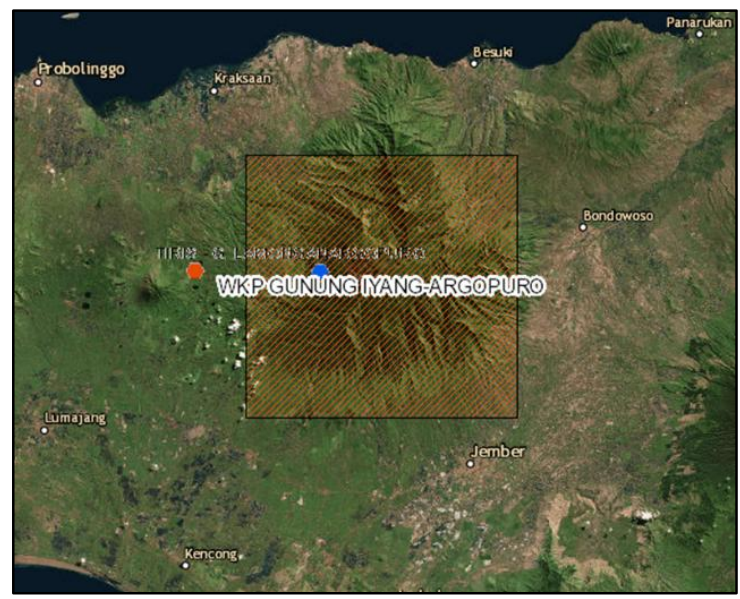

Fig 1. Mt. Iyang-Argopuro Geothermal Area Location Map

Mount Iyang Argopuro is currently in exploration stage based on SK WKP No 2067 K/30/MEM/2012 since 2012 by Ministry of Energy and Mineral Resources (MEMR). The prospect area is 106.500 ha and estimated to have water-dominated reservoir (MEMR, 2017)

Since no model of reservoir Mount Iyang-Argopuro are developed, this study aims to create a numerical model of Mount Iyang-Argopuro which represent the undisturbed condition or natural state condition of subsurface reservoir structure, heat and fluid flow inside the system, by integrating early obtained or exploration data. Numerical model is usually built using geoscience, well, and reservoir data (Di Pippo, 2012). However, in this study, the geoscience surveys are used as the main database to determine surface and subsurface conditions of the area since no deep hole has been drilled yet.

The reservoir model has been created using PETRASIM TOUGH2 simulator. Natural state condition is reached by matching the pressure and temperature parameter of simulation model to actual based on normal hydrostatic pressure and geochemical geothermometers.

The numerical model model can be used for further research. Numerical modeling aslo useful for reservoir resources assessment and future production performance prediction (Axelsson, 2012).

\section{Methodology}

The 3D numerical model is built based on geosciences data and conceptual model of the system. The grid-blocks system is created TOUGH2 simulator (Pruess et al., 2012).

Mount Iyang-Argopuro geoscience geothermal data is collected, such as conceptual models, geological, geophysical and geochemical data. These data are processed to obtain input simulator data in the TOUGH2 simulator.

After model is created and initial condition of the model is assigned. The model is simulated in unlimited time untill it reaches the steady state condition. The minimum time required is 1 million years in order to reach natural state condition (Vereina, 2005).

The model validation is done by matching the pressure and temperature profile from simulation results to calculated geothermometer and pressure gradient. If it does not shows a good match enough, an iterative calibration of input parameter should be done until it shows a good match. 


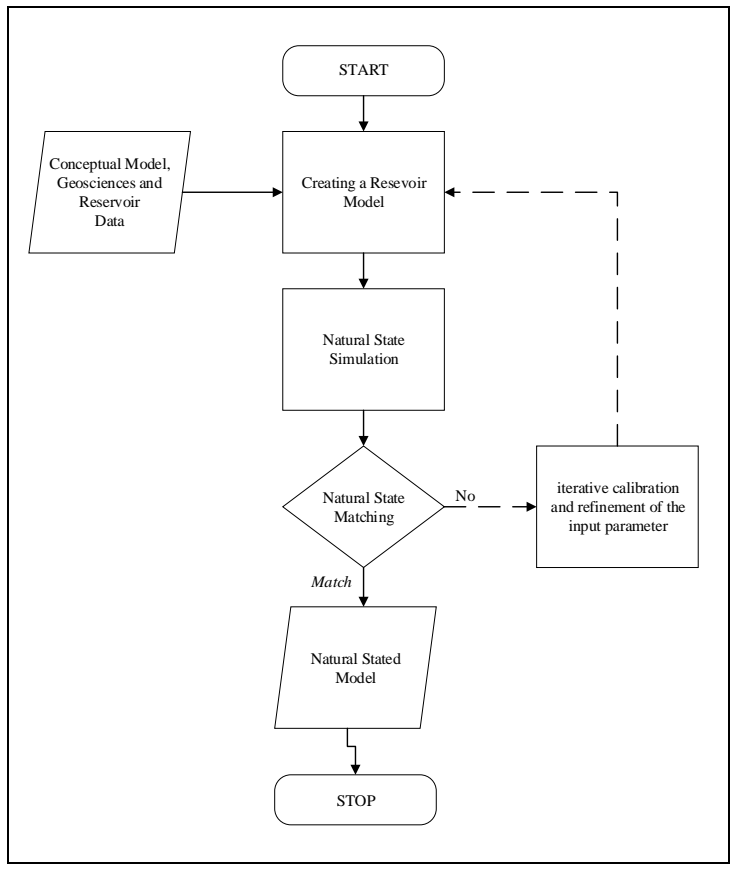

Figure 2. Research Flowchart

\section{Geoscience Data}

\subsection{Regional Geology and Geological Structure}

Mount Argopuro is located at Iyang Mountains but actually, it is in bigger mountains, Kendeng Mountains. It is streched from west to east of Eastern Java. This mountain range is biting with other mountains such as: Mount Semeru, Lawu, Bromo and Mount Raung (Purwanto et al., 2017)

The Mount Iyang Argopuro Geothermal Area consists of nature reserve $(0.02 \%)$, wildlife reserves $(12 \%)$, protected forests (around 38.5\%), permanent production forests (18.4\%), and other use areas (31\%) (MEMR, 2017).

The Argopuro Iyang region consists of volcanic rocks obtained by quaternary activity results of Old Mount Iyang-Argopuro and Young Mount Iyang-Argopuro. The evolution of volcanic activity shifts relative to the west, starting from Old Mount Iyang Argopuro (Mount Gilap and Mount Jembangan) to Young Mount Iyang-Argopuro (Mount Argopuro, Mount Semen and Mount Pandu) (MEMR, 2017).

The geological structure of the Iyang-Argopuro area consists of normal faults - shear directed towards NE-SW, $\mathrm{NW}$-SE and N-S. which controlling the appearance of the manifestation, such as solfatara in the crater of Cikasur, Cisentor, and Rengganis. Hot-warm springs in Cisentor, Tiris and Rabunan (MEMR, 2017).

According to Nainggolan et al. (2015), Old Argopuro deposition grouped into seven rock units, those are Lava and Pyroclastic Unit Mount Gilap (Qlpg), Lava and Pyroclastic Unit Cemorokandang (Qlpck), Lava and Pyroclastic Unit Mount Gendeng (Qlpgd), Lava and Pyroclastic Unit Mount Patrol (Qlpp), Lava and pyroclastic Unit Mount Malang (Qlpm), Lava and pyroclastic Unit Mount Siluman (Qlps) and Lava and pyroclastic Unit Mount Berhala (Qlpb).

This arrangement is sorted from old to young, with Lava and pyrocatstic Unit Mount Gilap (Qlpg) is the oldest one, while the Lava and Pyroclastic Unit Mount Berhala $(\mathrm{Qlpb})$ is the youngest. These unit are composed by basaltic andesite lava and the volcanic breccia. Basaltic andesite are dominant in all rocks unit than the volcanic breccia, except at Lava and Pyroclastic Unit Mount Malang (Qlpm)

Young Argopuro deposition grouped into three rock units, those are Lava Pyroclastic Unit Taman Hidup (Qlpth), Lava and Pyroclastic Unit Jambangan (Qlpj) and lava and pyroclastic unit Argopuro-dominant Rengganis (Qlpar). All three of these units can be equal with Post Caldera Iyang / Argopuro group.

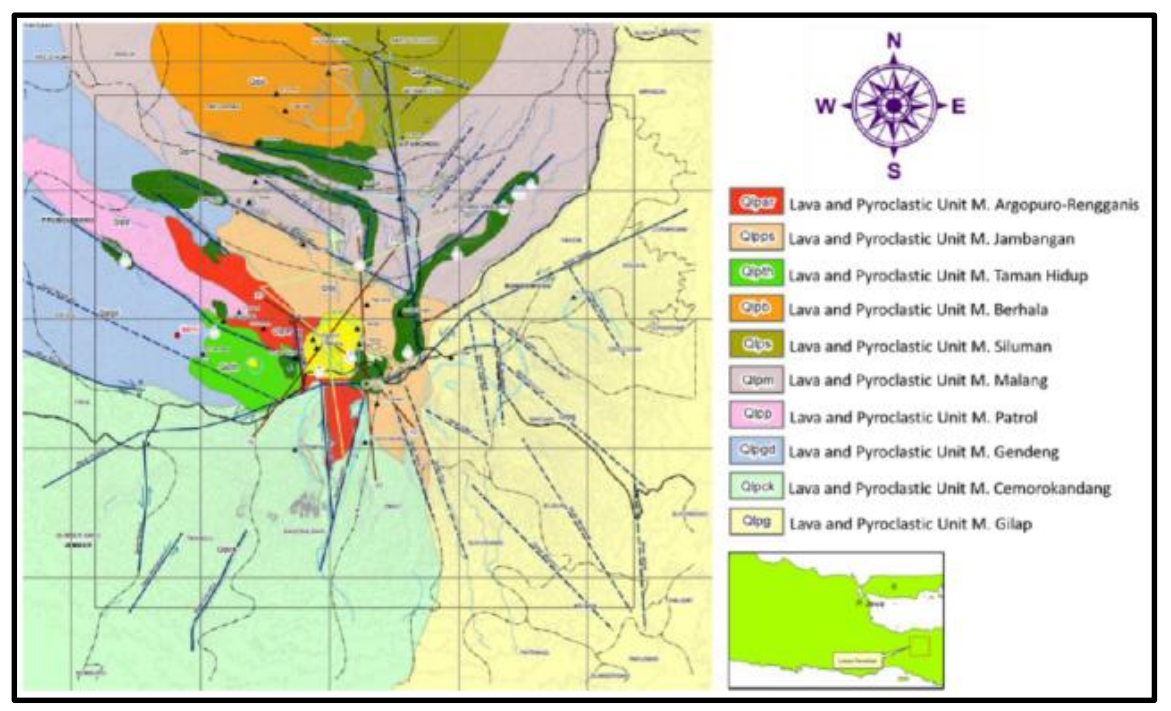

Figure 3. Mount Iyang-Argopuro Geological Map (Nainggolan et al., 2015)

Argopuro volcanic rocks consist of andesites basaltic, porphyry basalt, trachy basalt, and sometimes attractive altered breccia breccias, and micro-microbials suspected of breaking through volcanic rocks from Mount Argopuro products (Indarto, Fauzi, Gaffar, Abdullah, \& Utara, 2011)

\subsection{Geophysical Data}

\section{A. Gravity}

According Nainggolan et al. (2015) gravity anomaly colored in red indicating a volcanic neck of Mount Iyang- 
Argopuro which estimated to be the heat source of the system.

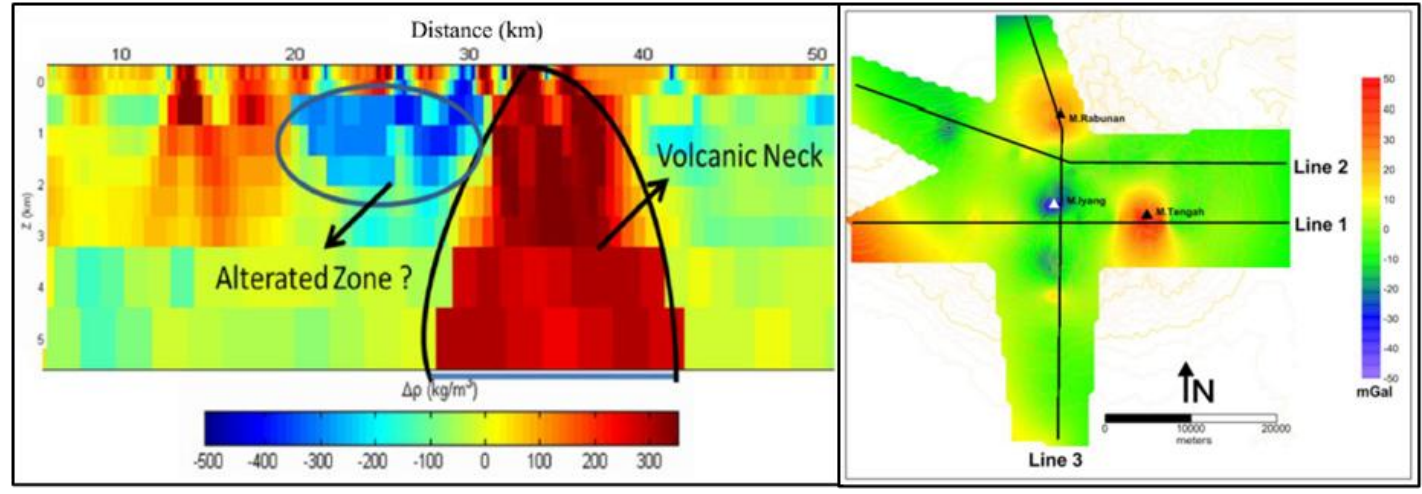

Fig 4. Gravity anomaly of Mount Iyang-Argopuro (Nainggolan et al., 2015)

Low anomaly in Peak of Mount Iyang Argupuro indicating that crater area is a prospect area. This statement is supported by the appearance of surface manifestations and alteration in the location.

\section{B. Magnetotelluric (MT)}

According to (Singarimbun et al., 2017) the system structure of Mount Iyang-Argopuro geothermal prospect is identified by four components by different range of resistivity distribution.
Mineral alteration is identified by the resistivity of less than $8 \mathrm{ohm}-\mathrm{m}$ at depth of $2000 \mathrm{~m}$. The lateral resistivity value distinction indicating fault structure. The resistivity distribution value over than $8 \mathrm{ohm}-\mathrm{m}$ is identified as reservoir rocks which located at depth of $2000 \mathrm{~m}-5000$ $\mathrm{m}$. Meanwhile, the resistivity distribution of over than $1024 \mathrm{ohm}-\mathrm{m}$ is identified as the heat source is located at $8000 \mathrm{~m}$ depth.

The MT data from Mount Iyang-Argopuro is shown in Figure 5 below
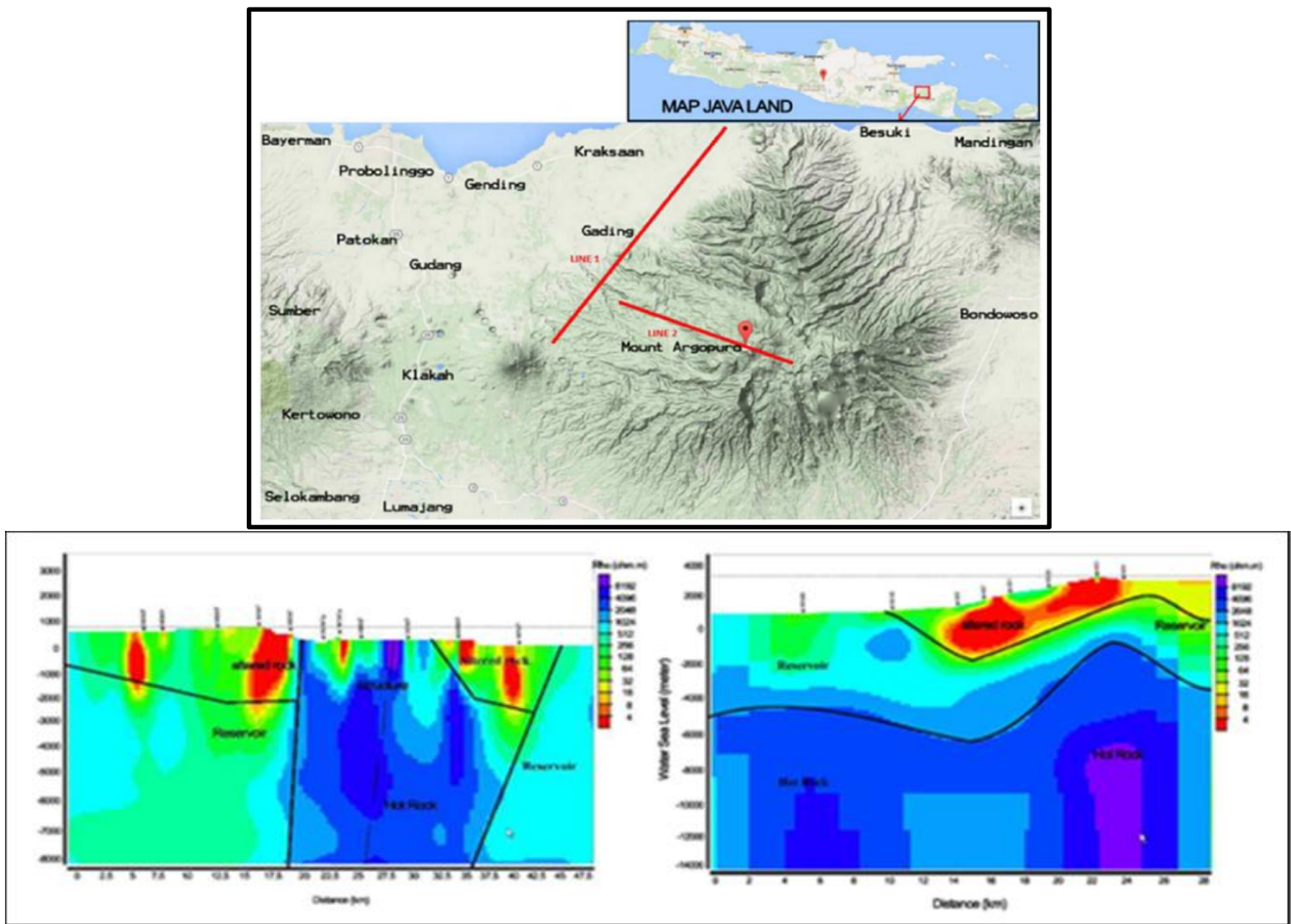

Fig 5. The MT Line and Inversion Results of Mount Iyang-Argopuro (Singarimbun et al., 2017)

\section{Geochemical Data}

Geothermal manifestations of Mount Iyang-Argopuro are hot spring in the Rabunan area, hydrothermal alteration, and fumarole.
Based on the results of geochemical analysis by Indarto, et al., (2011) $\mathrm{SiO} 2$ (106.50 - 108.17) $\mathrm{mg} / 1, \mathrm{HCO} 3$ (464.80 - 484.05) mg / 1, Cl (19.50- 24.94) mg / 1, so hot water is interpreted as a type of bicarbonate. Therefore the 
hot spring of this area is estimated to be an outflow zone due to the type of water indicated.

The alteration minerals indicate that in the Rabunan geothermal system at that time there is a change in temperature (Indarto et al., 2011)

Fumarole appears in the peak of Mount IyangArgopuro. The gas geotthermometer analysis (CARHAR) indicated that the reservoir temperature is approximately $275{ }^{\circ} \mathrm{C}$. The fomarole are identified to be upflow zone of the system. The gas component ratio $(\mathrm{H} 2 / \mathrm{Ar}, \mathrm{H} 2 \mathrm{~S} / \mathrm{Ar}, \mathrm{CO} 2 / \mathrm{H} 2, \mathrm{H} 2 \mathrm{~S} / \mathrm{H} 2)$ are indicating the reservoir temperature is $250{ }^{\circ} \mathrm{C}-275^{\circ} \mathrm{C}$.

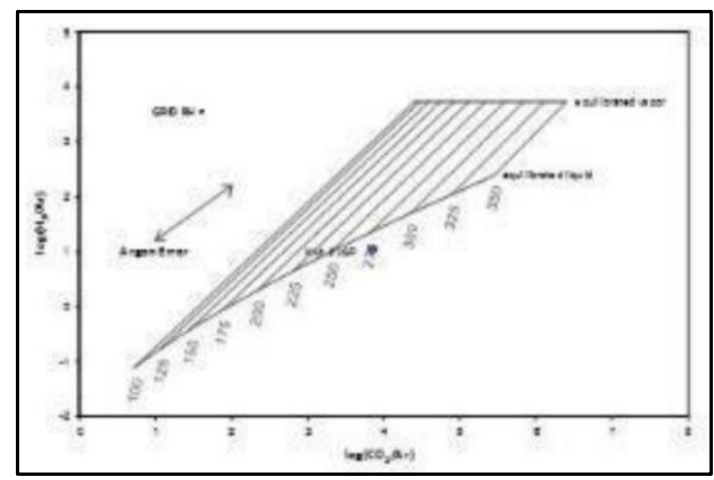

Fig 6. Gas Geothermometer (CAR-HAR) (MEMR, 2017)

\section{Conceptual Model}

The basis for constructing the conceptual model is the analysis of geological, geochemical, and geophysical information, temperature and pressure data, information about reservoir properties and information about the chemical content of reservoir fluids (Axxelson, G., 2013)

The conceptual model of Mount Iyang-Argopuro is shown in Figure 7.

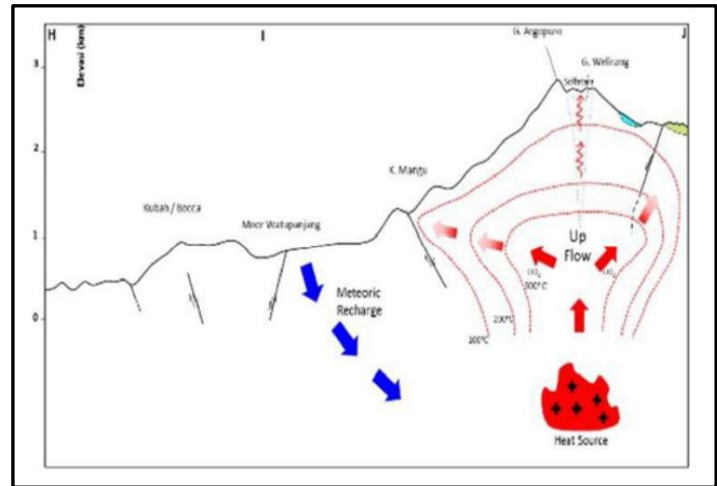

Fig 7. Conceptual Model of Mt. Iyang-Argopuro Geothermal System, East Java Province (MEMR, 2017)

Upflow zone located in Peak of Mount IyangArgopuro which is indicated by the appearance of solfatar and mineral alteration. The hot rock of the system also identified underneath Mount Iyang-Argopuro. The system is bounded by Sumbermalang Fault in the East, Cemara Lima in North.

\section{Model Description}

\subsection{Reservoir Boundary}

This model is created using a $12 \times 6.2 \mathrm{~km}$ reservoir area and addition of $1 \mathrm{~km}$ boundary in every side of model. The east and west reservoir boundaries use the consideration of magnetotelluric data (MT) cross-section $\mathrm{AC}$ (A from west to $\mathrm{C}$ from the east), the northern boundary of the reservoir area using consideration of the location of the manifestation of the hot spring shown in the Figure 8.

While the southern boundary is the limitation of this research problem. This southern boundary does not have any data yet, that can be used as consideration for determining the side boundary of the 3D model, so the assumption uses gravity data from the top view (in figure 2a).

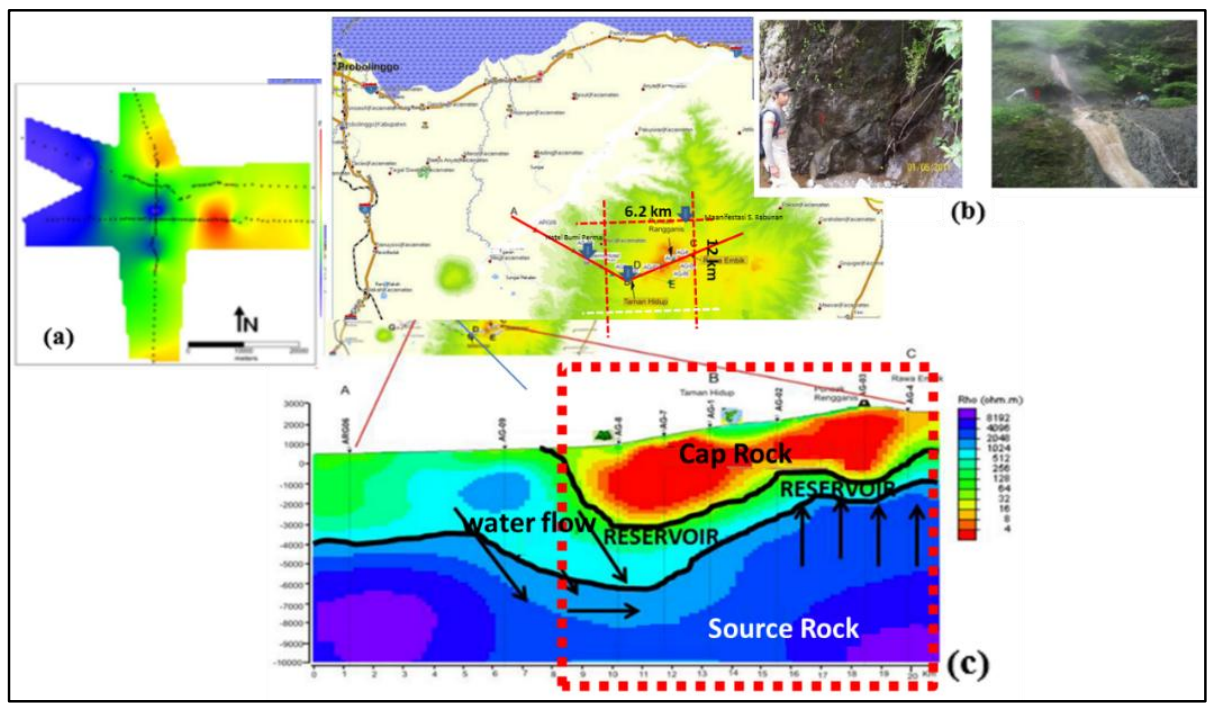

Fig 8. Reservoir Boundary Determination Based on MT, Gravity, and Manifestation Data (modified from Gaffar et al., 2012; Indarto et al., 2011; Nainggolan et al., 2015)

\subsection{Reservoir Thickness}

Reservoir thickness is identified from the MT survey, the vertical area has medium resistance about $30 \Omega \mathrm{m}-$
$1000 \Omega \mathrm{m}$. It is interpreted as a reservoir with $1000 \mathrm{~m}$ $3000 \mathrm{~m}$ depth. (Ghaffar, Indarto, \& Sudrajat, 2012)

\subsection{Grid System}


The 3D numerical model has of $14000 \mathrm{~m}$ in $\mathrm{x}$-axis, $8200 \mathrm{~m}$ in $\mathrm{y}$-axis, and $9180 \mathrm{~m}$ to $\mathrm{z}$-axis. The model consists of 7410 of rectangular cell blocks with the roughest cell size is $1000 \mathrm{~m} \mathrm{x} 1000 \mathrm{~m}$ and the finest is 200 $\mathrm{m} \times 500 \mathrm{~m}$.

This model has 19 layers with different layer thickness depending on the region. Several regions such as reservoir need to be fine in order to obtain accurate calibration. Generally, the model has thickness of $500 \mathrm{~m}$ in each layer, except at first layer $(200 \mathrm{~m})$ and the second layer (480 m).

Table 1. Layer Thickness of The Model

\begin{tabular}{lc}
\hline Layer & Thickness $(\mathrm{m})$ \\
\hline ATM & $200 \mathrm{~m}$ \\
\hline Layer 2 & $480 \mathrm{~m}$ \\
\hline Layer 3-19 & $500 \mathrm{~m}$ \\
\hline
\end{tabular}

The grid-blocks scheme of Mount Iyang-Argopuro numerical Model are shown in Figure 9 below.

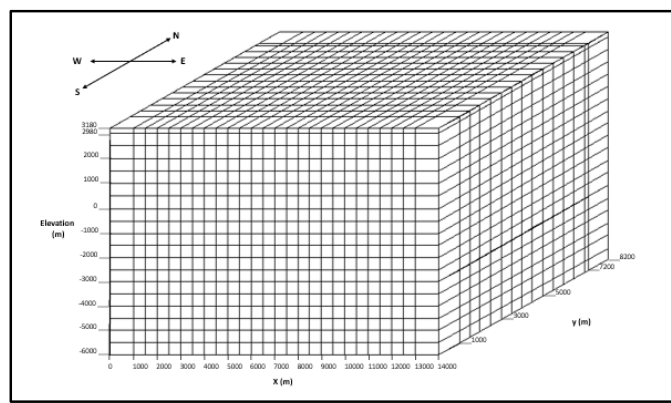

Fig 9. 3D Grid Blocks gor Numerical Model of Mt. IyangArgopuro Field

\subsection{Rock Properties}

Assign rock properties in each zone is the next step after creating a grid system. The rock properties consist of density, porosity, permeability ( $\mathrm{x}, \mathrm{y}, \mathrm{z}$ direction), thermal conductivity and specific heat. The most important parameter in a natural state is permeability which can control the fluid flow in geothermal system.

\subsection{Top Boundary}

The top boundary is made into an atmospheric condition. It is assigned at the top surface with 1 bar for pressure and $25{ }^{\circ} \mathrm{C}$ for temperature. The top boundary is assigned to have a huge volume factor to ensure the atmosphere does not affected by reservoir condition (Firdaus, Sutopo, \& Pratama, 2016).

\subsection{Side Boundary}

All side boundary is set to be a no-flow boundary which means the boundary has a very low permeability. The model is designed to make sure that no flow of mass or heat from and into the system from the lateral side.

\subsection{Bottom Boundary}

The bottom boundary is the heat source. It is set for $350{ }^{\circ} \mathrm{C}$ of temperature and 7.2E07 of pressure. The heat source volume factor is set at $1.0 \mathrm{E} 36$ to ensure the pressure and temperature of heat source have a proper influence in the system.

\subsection{Initial Condition}

To accelerate the modeling process, we have to create an initial condition to assign pressure and temperature value each grid blocks. In this model, we will use linear pressure and temperature gradients. For temperature, thermal gradient of $3^{\circ} \mathrm{C} / 100 \mathrm{~m}$ is used in this this model. And for pressure, hydrostatic gradient of $0.0979 \mathrm{bar} / \mathrm{m}$. Both gradients applies to every depth from the surface.

Table 2. Material Properties

\begin{tabular}{lll}
\hline \multirow{2}{*}{ Layer } & \multicolumn{2}{c}{ Permeability $\left(\mathrm{m}^{3}\right)$} \\
\cline { 2 - 3 } & Horizontal & Vertical \\
\hline ATM & $1.0 \mathrm{E}-13$ & $1.0 \mathrm{E}-13$ \\
\hline CAPR & $1.0 \mathrm{E}-18$ & $1.0 \mathrm{E}-18$ \\
\hline RES 1 & $8,0 \mathrm{E}-15$ & $4,0 \mathrm{E}-15$ \\
\hline RES 2 & $1,0 \mathrm{E}-14$ & $5,0 \mathrm{E}-15$ \\
\hline ALTR & $1,0 \mathrm{E}-14$ & $5,0 \mathrm{E}-15$ \\
\hline HS & $3,0 \mathrm{E}-15$ & $1.0 \mathrm{E}-15$ \\
\hline BOND & $1.0 \mathrm{E}-18$ & $1.0 \mathrm{E}-18$ \\
\hline
\end{tabular}

The material is assigned to the model based on the distribution of rock properties derived from MT survey. The distribution of material in the model is shown in the Figure 10.

The top material is atmosphere to represent the earth surface condition. The atmosphere is assigned in top layer to layer 6 . Followed by thick clay cap rock layer which is lies varies from layer 2 to layer 13 . Beneath the cap rock, lies the main reservoir which has average thickness of $1000 \mathrm{~m}$. Then followed by hot rocks which in this model is stated as reservoir 3 or ALTR. The heat source is assigned to 9 blocks at the bottom of model at depth of $8000 \mathrm{~m}$.

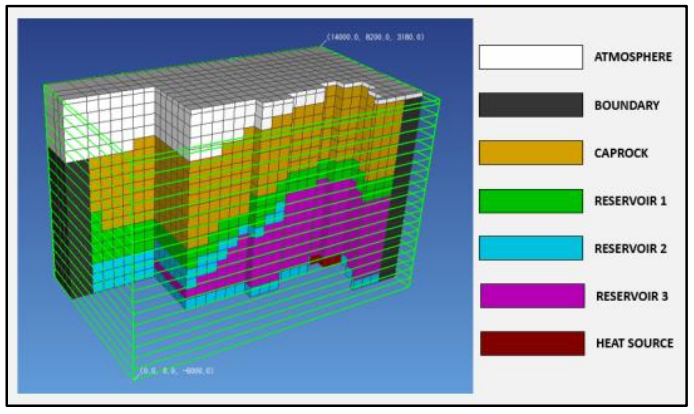

Fig 10. Distribution of Rock Types in Layers

\section{Result And Discussion}

Natural state condition is the initial condition of unexploited geothermal system and before any production. Natural state validation in this model done by temperature matching between the model temperature and geothermometer estimation.

Since no deep hole well drilled yet. A synthetic well is made in the model in order to measure the model temperature and pressure. The sintetic well located at model coordinate x,y $(9250,4450)$. This well has a depth of $4500 \mathrm{~m}$ from the surface to the reservoir zone.

Hot mass is injected through 9 blocks of heat source with the total mass flow of $5 \mathrm{~kg} / \mathrm{s}$. Then the model is simulated.

After the simulation, the recorded temperature and pressure is subject to later matching with the calculation of geothermometer and pressure gradient. Mount IyangArgopuro numerical model reaches the natural state and steady-state condition after 2,23 billion years of simulation. 


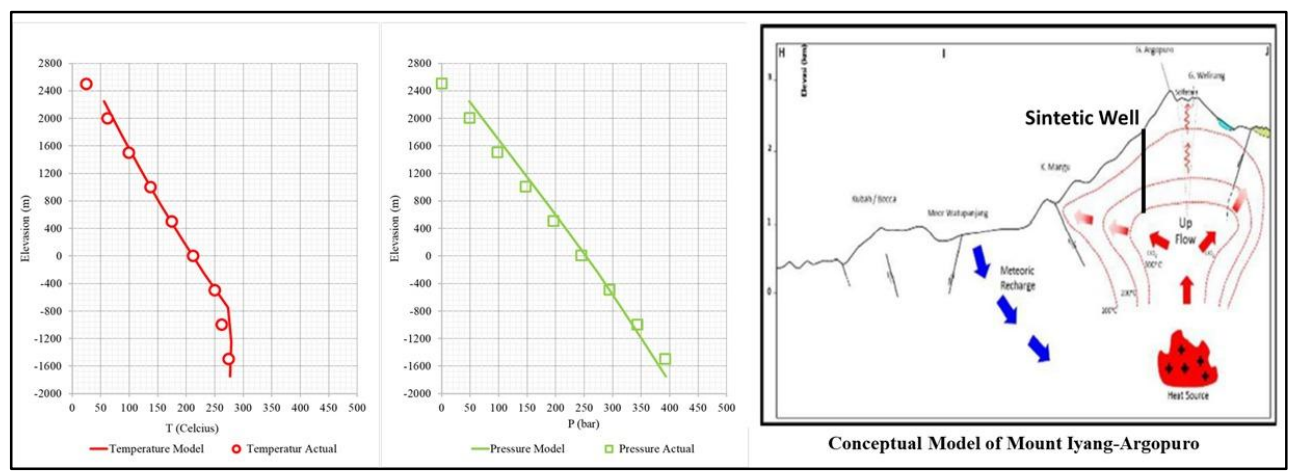

Fig 11. Temperature and Pressure Result

From the Figure 11, the identical trendline is shown beetwen model and actual for both temperature and pressure. The temperature recorded in the reservoir is 260$270^{\circ} \mathrm{C}$, which shows a good match enough between model and the geothermometer calculation which is around 275 ${ }^{\circ} \mathrm{C}$.

The heat transfer from the top of reservoir, along the cap rock, to the surface is identified as a conduction heat flow as the temperature gradient is relatively slant. While convective heat flow is identified in the reservoir from the vertical temperature gradient of fluid.
Besides matching the temperature and pressure, It is important to identify the mass and heat flow from heat source to the entire system.

Based on simulation results in Figure 12 and Figure 13, the hot mass from the bottom of Mt. Argopuro is flowing upward, toward the peak of Mt. Argopuro. This phenomenon is identified as upflow zone which is correspond to the existence of surface manifestation in the form of fumarole at Rengganis Peak.
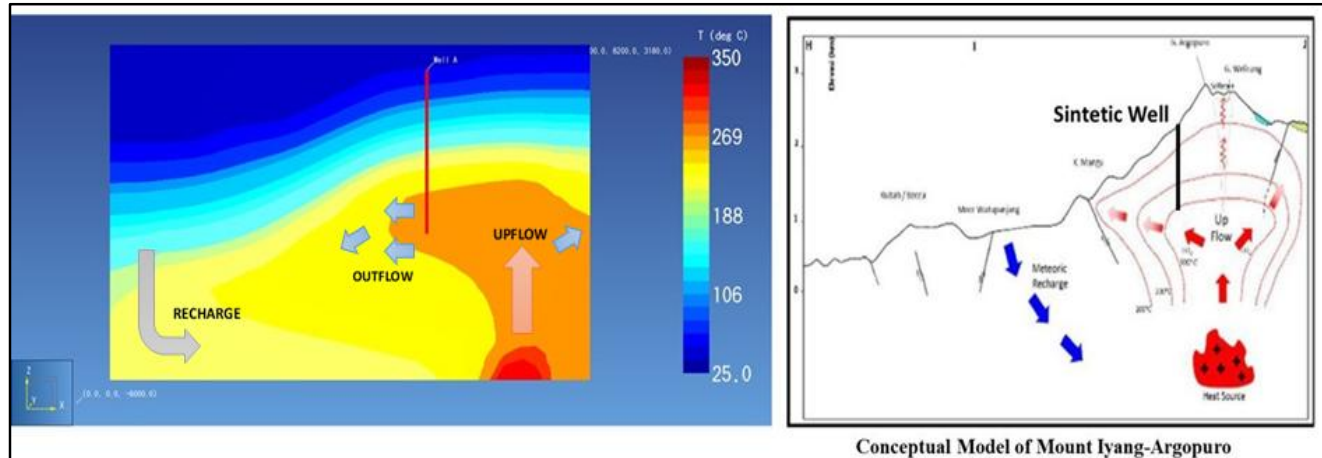

Fig 12. Model Heat Flow Compared to Conceptual Model

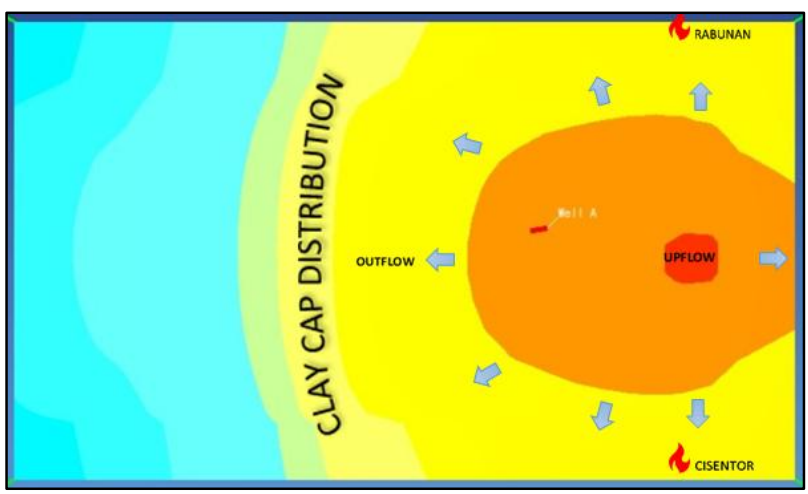

Fig 13. Model Heat Flow in Horizontal Cross Section

The hot mass then filling the reservoir zone through the system faults (NE-SW) towards west following the clay cap distribution. A portion of mass also flows towards north and south which is indicated by the emergence as hot water manifestation in Rabunan and Cisentor. These phenomena are the outflows of the system such as in Figure 12 and 13.

The cold water, which is identified as recharge water is flowing throgh western part of the system and then flows downward through the geothermal fault system and eastward into the system heat source and reservoir. This phenomenon is match to the prediction of recharge zone in the conceptual model of the system.

\section{Conclusions}

The 3D natural state numerical model model of liquiddominated reservoir of Mount geothermal area has been developed based on geosciences data since limited petrophysical data available. 
The model is validated by matching the model temperature and pressure to the calculation of geothermometer and pressure gradient after being simulated for 2.23 billion years.

The reservoir temperature reaches $260-270^{\circ} \mathrm{C}$ and shows a good match to the gaothermometer calculation.

The mass and heat flows in the model are similar to the conceptual model where the hot mass is flow upward into peak of Mt Argopuro and filling the reservoir into west direction.

\section{Acknowledgement}

The authors would like to thank the Directorate General of Renewable Energy and Energy Conservation (DG EBTKE) and the Ministry of Energy and Mineral Resources (MEMR) for supporting this research, providing Mt. Iyang Argopuro exploration data which is consent for publication.

\section{References}

Axelsson, G. (2012). Role and management of geothermal reinjection. Presented at "Short Course on Geothermal Development and Geothermal Wells", Organized by UNU-GTP and LaGeo, in Santa Tecla, El Salvador, March 11-17, 2012., 1-21.

DiPippo, R. (2012). Geothermal Power Plants: Principles, Applications , Case Studies and Environmental Impact (3rd ed.). https://doi.org/10.1016/B978-0-08-0982069.00024-5

Firdaus, F., Sutopo, \& Pratama, H. B. (2016). The Natural State Numerical Model of Patuha Geothermal Reservoir, Indonesia. Proceedings 4th Indonesia International Geothermal Convention \& Exhibition, (4), 1-13. Jakarta: Asosiasi Panas Bumi Indonesia.

Gaffar, E. Z., Indarto, S., \& Sudrajat, Y. (2012). Pencitraan Struktur Internal Gunung Iyang Prospek Panas Bumi.
Prosiding Pemaparan Hasil Penelitian Pusat Penelitian Geoteknologi LIPI, 361-373. LIPI.

Indarto, S., Fauzi, A., Gaffar, E. Z., Abdullah, A. K., \& Utara, S. (2011). Manifestasi permukaan panasbumi daerah rabunan, gunung argopuro, jawa timur berdasarkan mineralogi dan kimia unsur utama. 53-61.

MEMR. (2017). Potensi Panas Bumi Indonesia Jilid 1. Jakarta: Direktorat Panas Bumi.

Nainggolan, S. S., Sastranegara, R. M. T., \& Raharjo, I. B. (2015). Volcanic Neck of Mount Iyang Argopuro Revealed From Gravity Study. World Geothermal Congress, (April), 1-4

Pruess, K., Oldenburg, C., \& Moridis, G. (2012). TOUGH2 USER'S GUIDE, VERSION 2.

Purwanto, M. S., Bashri, A., Harto, M., \& Syahwirawan, Y. (2017). Citra Satelit Landsat 8 + Tris Sebagai Tinjauan Awal Dari Manifestasi Panas Bumi Di Wilayah Gunung Argopura. Jurnal Geosaintek, 3(1), 13. https://doi.org/10.12962/j25023659.v3i1.2951

Singarimbun, A., Gaffar, E. Z., \& Tofani, P. (2017). Modeling of reservoir structure by using magnetotelluric method in the area of Mt. Argopuro, East Java, Indonesia. Journal of Engineering and Technological Sciences, 49(6), 833-847. https://doi.org/10.5614/j.eng.technol.sci.2017.49.6.9

Vereina, O. B. (2005). Numerical Modelling of the Natural State of the Mutnovsky Geothermal Reservoir (Kamchatka, Russia). Proceedings World Geothermal Congress 2005, (April), 1-8. https://doi.org/10.1134/S002449020706003X 